\title{
Acute and long-term grief reactions and experiences in parentally cancer-bereaved teenagers
}

Tove Bylund-Grenklo ${ }^{1 *+}$, Dröfn Birgisdóttir ${ }^{2^{*}+}$, Kim Beernaert ${ }^{3,4}$, Tommy Nyberg ${ }^{5,6}$, Viktor Skokic ${ }^{6}$, Jimmie Kristensson ${ }^{2,7}$, Gunnar Steineck ${ }^{6,8}$, Carl Johan Fürst ${ }^{2}$ and Ulrika Kreicbergs ${ }^{9,10}$

\begin{abstract}
Background: Previous research shows that many cancer-bereaved youths report unresolved grief several years after the death of a parent. Grief work hypothesis suggests that, in order to heal, the bereaved needs to process the pain of grief in some way. This study explored acute grief experiences and reactions in the first 6 months post-loss among cancer-bereaved teenagers. We further explored long-term grief resolution and potential predictors of having had "an okay way to grieve" in the first months post-loss.

Methods: We used a population-based nationwide, study-specific survey to investigate acute and long-term grief experiences in 622 (73\% response rate) bereaved young adults (age > 18) who, 6-9years earlier, at ages 13-16 years, had lost a parent to cancer. Associations were assessed using bivariable and multivariable logistic regression.

Results: Fifty-seven per cent of the participants reported that they did not have a way to grieve that felt okay during the first 6 months after the death of their parent. This was associated with increased risk for long-term unresolved grief (odds ratio (OR): 4.32, 95\% confidence interval (CI): 2.99-6.28). An association with long-term unresolved grief was also found for those who reported to have been numbing and postponing (42\%, OR: 1.73, $95 \% \mathrm{Cl}: 1.22-2.47)$, overwhelmed by grief (24\%, OR: $2.02,95 \% \mathrm{Cl}: 1.35-3.04)$ and discouraged from grieving (15\%, OR: $2.68,95 \% \mathrm{Cl}: 1.62-4.56)$ or to have concealed their grief to protect the other parent (24\%, OR: $1.83,95 \% \mathrm{Cl}$ : 1.23-2.73). Predictors of having had an okay way to grieve included being male, having had good family cohesion, and having talked about what was important with the dying parent.

(Continued on next page)
\end{abstract}

\footnotetext{
* Correspondence: tove.bylund.grenklo@hig.se; drofn.birgisdottir@med.lu.se

${ }^{\dagger}$ Tove Bylund-Grenklo and Dröfn Birgisdóttir contributed equally to this work and share co-first authorship.

'Department of Caring Science, Faculty of Health and Occupational Studies, University of Gävle, SE-801 76 Gävle, Sweden

${ }^{2}$ Faculty of Medicine, Department of Clinical Sciences Lund, Oncology and Pathology, Institute for Palliative Care, Lund University and Region Skåne, Medicon Village, Hus 404B, 22381 Lund, Sweden

Full list of author information is available at the end of the article
}

(C) The Author(s). 2021, corrected publication 2021. Open Access This article is licensed under a Creative Commons Attribution 4.0 International License, which permits use, sharing, adaptation, distribution and reproduction in any medium or format, as long as you give appropriate credit to the original author(s) and the source, provide a link to the Creative Commons licence, and indicate if changes were made. The images or other third party material in this article are included in the article's Creative Commons licence, unless indicated otherwise in a credit line to the material. If material is not included in the article's Creative Commons licence and your intended use is not permitted by statutory regulation or exceeds the permitted use, you will need to obtain permission directly from the copyright holder. To view a copy of this licence, visit http://creativecommons.org/ licenses/by/4.0/. The Creative Commons Public Domain Dedication waiver (http://creativecommons.org/publicdomain/zero/1. 0/) applies to the data made available in this article, unless otherwise stated in a credit line to the data. 
(Continued from previous page)

Conclusion: More than half of the cancer-bereaved teenagers did not find a way to grieve that felt okay during the first 6 months after the death of their parent and the acute grief experiences and reaction were associated with their grief resolution long-term, i.e. 6-9 years post-loss. Facilitating a last conversation with their dying parent, good family cohesion, and providing teenagers with knowledge about common grief experiences may help to prevent long-term unresolved grief.

Keywords: Adolescents, Bereavement, Cancer, Grief, Loss, Mourning, Oncology, Parental death, Teenagers, Unresolved grief, Young adults

"I remember once waking up in the middle of the night with an excruciating pain in my heart. It was stabbing, aching and burning. If I had not been told that psychological pain can manifest itself in physical pain I would have thought that I was dying that night. The pain was so intense; I think my heart broke in thousands of pieces that night.

Today, eight years later, my heart is no longer in thousands of pieces - at least not for any longer period of time."

Quote from one of the participants, a daughter who at age 14 lost her mother [1](p.31).

\section{Introduction}

Undoubtedly, for a child, one of the most devastating experiences is the early death of a parent, which can seriously affect their health and wellbeing [2-7] in the short and long term. Bereavement in children and adolescents has been shown to be associated with increased risk of suicide attempts $[8,9]$ and increased mortality [10, 11], and previous research based on the same study sample as the current study showed almost a doubled risk of self-injury in the first 6-9 years following teenage bereavement $[12,13]$. While not all bereaved children and adolescents will face these negative outcomes of bereavement [14, 15], risk factors such as sudden, unexpected or traumatic [5] loss, parental depression [16] and poor family cohesion $[17,18]$ have been identified. Complicated or prolonged grief is another factor that has been shown to be associated with those negative healthrelated outcomes in bereaved children and adolescents $[19,20]$. This includes symptoms such as separation distress, pre-occupation with thoughts about the deceased person, and difficulties in accepting the loss or in returning to normal functioning after the loss [21-23]. It should be noted that the categorization of complicated or prolonged grief is still debated, particularly in children and adolescents [24, 25].

In bereaved adults, the characteristics of the grieving process are considered to be of importance for their wellbeing after bereavement [26-28]. In the immediate phase after bereavement, grief may often include powerful emotions such as shock, numbness, crying, anxiety and anger [29, 30] and many theories concerning coping with or recovering from loss, regardless of whether they focus on stages [11] or tasks [12], include the notion that, in order for the person to heal, they must deal with the pain in so-called "grief work". Since Freud first came forward with this notion, the understanding of what "working through the grief" entails has changed over time [31], challenging the assumption that "grief work" is only a cognitive process of confronting the loss [31]. This can be seen in one of today's relevant grieftheories, the Dual Process Model, stating that it is part of the normal grieving process for people to shift in and out of the intense emotional reaction to loss, described as oscillation between loss- and restoration-oriented grief reactions [32]. The Dual Process model was initially designed to understand conjugal bereavement [31] and yet more research is needed to build up the empirical evidence among bereaved children and teenagers. Grief is a unique experience and is highly influenced by individual traits, the relationship with the deceased and the circumstances surrounding the death, as well as social and cultural factors [25], and grief reactions among children and teenagers can differ from adults' reactions [33]. Children and teenagers can often only tolerate the emotional pain for a short period of time compared with adults, shifting between intense feelings such as yearning, sadness or anger to rapidly returning to normal activities [33-35]. It has been highlighted that more knowledge is needed about the grieving process of children and teenagers [36-38] and many experts in the field seem to agree that not all knowledge from the adult bereavement research field can be transferred directly to children and teenagers [24]. Knowledge on various grief reactions of children and teenagers can be helpful for both bereaved children and their parents while dealing with the loss [39-41]. Nevertheless, for the last decades, the focus within the bereavement literature has mostly been on what is sometimes referred to as "pathological grief responses" among children and teenagers, while more research is also needed to better understand "normative grieving processes " [25]. While knowledge 
regarding e.g. the needs of, and the meaning of grief in bereaved children, adolescents and young adults are increasingly being documented [42-44], we still need more knowledge about the youths'reactions and experiences of grief, in the immediate phase and long-term [24, 37].

To be able to provide more knowledge and to reduce suffering among parentally bereaved teenagers, more research based on teenagers' own experience is needed to describe their normative and pathological grieving processes [25] both during the acute bereavement phase and long-term.

In the preparatory interviews with cancer-bereaved youths that were performed for this research project, the parentally bereaved informants described a range of different grief reactions in the immediate post-loss phase. Some concluded that they had not found "an okay way to grieve" (data not published).

The aim of this exploratory population-based study was to investigate 1) the prevalence of a set of grief experiences and reactions in the acute bereavement phase, i.e. the first 6 months post-loss, and 2) their possible associations with unresolved grief long-term, 6-9 years after the loss of a parent to cancer, as self-assessed by cancer-bereaved youths. Further, we explored the associations between demographic, family, and health carerelated factors, and the experience of having had an okay way to grieve in the first 6 months post-loss.

\section{Method}

\section{Study design and study population}

We conducted a population-based nationwide survey in 2009-2010 in young adults who, during their teenage years, had lost a parent to cancer. The Swedish Cause of Death Register identified the individuals who had died from cancer at an age younger than 65 (based on International Classification of Diseases, 10th revision (ICD10), codes C00-C96) in 2000-2003. This information was then used by the Multi-Generation Register to identify children who were bereaved of a parent between the ages of 13 and 16 and who had been living with both parents at the time of the loss. Because of the great variation in maturity levels during the teenage years [45], we decided to restrict this study to the youngest group of teenagers that would match grades 7 to 9 in the Swedish middle school.

For inclusion, the participants had to be living in Sweden at the time of the survey, be fluent in Swedish, and have an identifiable telephone number; also, their other parent still had to be alive. Altogether, 851 bereaved former teenagers were confirmed eligible for the study. All participants were between 18 and 26 years old at the time of the data collection. More details on the study protocol have been published elsewhere [46].

\section{Data collection}

At the beginning of the data collection, each participant first received an introductory letter explaining the study objective. A questionnaire was sent only to those who, during a subsequent informative telephone call, consented to participate. Participants were informed both orally and in writing about their right to withdraw from the study at any time. The questionnaires were returned in pre-stamped envelopes, separately from the response cards in order to ensure anonymity. After a few weeks, a combined thank you and reminder card was posted, followed by reminder telephone calls to those whose responses were missing.

\section{Questionnaire development}

A study-specific questionnaire was developed based on semi-structured interviews with 15 cancer-bereaved youths, and interviews with three health care professionals specialized in grief and palliative care, as well as the bereavement literature. To ensure that the questions we constructed were understood as intended, we tested the face validity of the questionnaire and response options with 15 cancer-bereaved former teenagers (six previously interviewed and nine newly invited individuals) in think-aloud interviews. Questionnaire development followed well-established routines that have been previously described [47, 48]. The final questionnaire contained 271 question items, set in different time frames, i.e. childhood, teenage years (before and after the loss), and young adulthood (at the time of the survey). A total of 37 items were considered relevant for this study.

\section{Measurements}

We used six single-item questions [49] to assess coping styles, grief experiences, expressions and behaviours in the acute bereavement phase, i.e. during the first 6 months after the loss of a parent (hereafter referred to as "Acute grief experiences and reactions"). These questions all started with "For the first half-year after your loss, would you agree with the statement: ..." , followed by:

- "I had a way to grieve that felt okay." (hereafter labelled: Had an okay way to grieve, or as its negative counterpart; Did not have an okay way to grieve $(R)$ for its reversed form)

- "I clenched my teeth, built a wall around me and lived on as if nothing had happened." (Numbing and postponing)

- "I withheld my grief to protect my other parent." (Concealed grief)

- "The grief was so strong it felt as if I would not survive, as if I was going crazy or was not normal." (Overwhelmed by grief) 
- "People stopped me from grieving by drawing away when I was sad or praising me when I was being strong." (Discouraged from grieving)

- "There was pressure from others that I should be more sad than I was showing." (Pressured to grieve)

The response options for all abovementioned questions were: "Completely agree", "Moderately agree", "Slightly agree" and "Do not agree at all".

Long-term grief resolution, i.e. at the time of the survey (6-9 years after the loss), was measured with the single-item question:

- "Have you worked through your grief?", with the response options "No, not at all", "Yes, a little", "Yes, moderately" and "Yes, completely".

This single-item question was well understood by bereaved participants in the face-validity interviews and has been used in previous studies [17, 50-53]. In a study on young adults, cancer-bereaved of a sibling, this question was validated against three questions from the Inventory of Complicated Grief (ICG), and found to be strongly correlated to them [53].

Additionally, we used ten demographic variables (e.g. gender of the child), three family-related variables (e.g. family cohesion), and 15 health care-related variables (e.g. teenagers' level of trust in the health care provided to the dying parent in the final week of life) in our data analysis.

\section{Data analysis}

The responses to all of the items measuring the grief experiences and reactions during the acute bereavement phase (the first 6 months post-loss) were dichotomized into "Agree" (moderately, and completely agree) and "Disagree" (slightly agree, and do not agree at all). The responses "No" and "Yes, a little" to the question of having worked through grief were labelled as "Unresolved grief" while "Yes, moderately" and "Yes, completely" were labelled as having worked through grief.

The relationship between the six acute grief experiences and reactions in the first 6 months following the loss, and perceived unresolved grief at follow-up was evaluated in terms of odds ratios (ORs). The unadjusted estimates were calculated using logistic regression which was then subsequently adjusted for three groups of possible confounders. The adjustment scheme applied decomposes into two steps. In the first step, all of the available possible confounders were classified as belonging to one of the classes "background variables", "familyrelated variables" and "health care-related variables". Within each group a logistic regression with a forward selection procedure was performed, using the variables as predictors of "unresolved grief at follow-up". Selection was based on likelihood ratio $p$-values, with a $p$-value of 0.25 used as a stopping criterion. This means that the selection procedure was aborted if none of the remaining candidate variables were associated with a $p$ value of 0.25 or less when included in the model. Prior to each selection all individuals with missing values on any of the variables within a particular group of variables were excluded. In the second step, the groups of variables selected by the forward selection procedures were sequentially used to calculate the adjusted ORs with $95 \%$ confidence intervals (CIs).

A further analysis of the data was performed, where both crude and adjusted ORs were calculated again with the same three groups of possible confounders as before, but now with the data stratified by the gender of the participants.

In order to assess what variables might be associated with Having had an okay way to grieve in the 6 months following the loss, all variables considered in the previous analysis were treated as potential predictors of this outcome in bivariable logistic regression models. Once again likelihood ratio $p$-values were used to evaluate their predictive performance. The significant variables ( $p$-value $<0.05)$ were subsequently used in conjunction as predictors in a multivariable logistic regression model, in order to investigate the effect of correlations among them on their significance as predictors.

\section{Results}

A total of 851 cancer-bereaved youths (teenagers at the time of their loss) were confirmed eligible, 622 (73\%) of whom returned the questionnaire. Fifty-four per cent of participants had lost their father and $46 \%$ had lost their mother. The characteristics of the participants are presented in Table 1.

\section{Prevalence of the different acute grief experiences and reactions}

Among the participants, 57\% reported that they had not had an okay way to grieve (R), as can be seen in Table 2 . The most often agreed with out of the remaining five acute grief reactions were numbing and postponing (42\%), concealed grief to protect the other parent (25\%) and being overwhelmed by grief (24\%). A total of 79 participants, or $13 \%$, disagreed with all of the statements regarding grief during the acute bereavement phase.

\section{Associations between the acute grief reactions and long- term unresolved grief}

Forty-five per cent of the participants reported not having worked through their grief at the time of the survey 6-9 years post-loss. Table 3 shows the associations between the six acute grief experiences and reactions in 
Table 1 Characteristics of the study population

\begin{tabular}{ll}
\hline & N (\%) \\
\hline Confirmed eligible $^{1}$ & $\mathbf{8 5 1 ( 1 0 0 )}$ \\
Unreachable & $55(6)$ \\
Declined to participate & $66(8)$ \\
Agreed initially but did not return the questionnaire & $108(13)$ \\
Provided information & $\mathbf{6 2 2 ( 7 3 )}$
\end{tabular}

Gender of the participants

$\begin{array}{ll}\text { Male } & 309(50) \\ \text { Female } & 312(50) \\ \text { Not stated } & 1\end{array}$

Year of birth (age, in years, at the time of the survey)

$\begin{array}{ll}1988-1990(19-21) & 210(34) \\ 1986-1987(22,23) & 286(46) \\ 1984-1985(24-26) & 123(20) \\ \text { Not stated } & 3\end{array}$

Birth order

Oldest child

144 (23)

Middle child

148 (24)

Youngest child

$302(49)$

Only child

$27(4)$

Not stated

Living arrangement and marital status

Lives with parent, is single

Lives with parent, has a partner (living apart)

Has moved away from parent, is single

$153(25)$

Has moved away from parent, has a partner (living 86 (14)

apart)

Lives with partner or spouse

Not stated

3

Highest level of education attained (at the time of the survey)

$\begin{array}{ll}\text { Not applicable, never graduated } & 6(1) \\ \text { Middle school ( } \leq 9 \text { th grade) } & 49(8) \\ \text { High school ( } \geq 10 \text { th grade) } & 501(81) \\ \text { College/university } & 54(9) \\ \text { Other type of studies } & 11(2) \\ \text { Not stated } & 1\end{array}$

\section{Current employment status ${ }^{2}$}

Studying at high school level

Adult education at high school level

Studying at university level

Employed or self-employed

Unemployed

On parental leave

On sick leave

$31 / 613(5)$

$187 / 613$

(30)

$355 / 616$

(58)

$91 / 616(15)$

$9 / 613(2)$

$7 / 613(1)$
Table 1 Characteristics of the study population (Continued)

\begin{tabular}{|c|c|}
\hline & $\mathrm{N}(\%)$ \\
\hline \multicolumn{2}{|l|}{ Residential area } \\
\hline Rural & $54(9)$ \\
\hline Small village or town & $113(18)$ \\
\hline Medium-sized town & $283(46)$ \\
\hline City of more than 500,000 & $166(27)$ \\
\hline Not stated & 6 \\
\hline \multicolumn{2}{|c|}{ Gender of the deceased parent } \\
\hline Male & $337(54)$ \\
\hline Female & $284(46)$ \\
\hline Not stated & 1 \\
\hline
\end{tabular}

the first 6 months post-loss and reported unresolved grief 6-9 years later (i.e. at the time of the survey). The participants reporting not having had an okay way to grieve $(R)$ were statistically significantly more likely to report long-term unresolved grief (OR: 4.32, 95\% CI: 2.99-6.28). Statistically significant associations with unresolved grief long-term were also found in those who reported to have been numbing and postponing (OR: 1.73, 95\% CI: $1.22-2.47)$, to have been overwhelmed by grief (OR: 2.02, 95\% CI: 1.35-3.04), to have been discouraged from grieving (OR: 2.68, 95\% CI: 1.62-4.56) and to have concealed their grief to protect the surviving parent (OR: 1.83, 95\% CI: 1.23-2.73). All these associations remained statistically significant after controlling for the selected possible confounding demographic variables, family-related variables and health care-related variables (Table 3).

\section{Gender-stratified analysis}

Forty-nine per cent of the parentally cancer-bereaved male participants and $65 \%$ of the female participants reported not having had a way to grieve that felt okay (R) to them during the acute bereavement phase. Figure 1 illustrates the reported prevalence of the different grief experiences and reactions during the acute bereavement phase, subdivided by gender. Figure 2 shows the reported prevalence of grief resolution 6-9 years after the loss of a parent, where $37 \%$ of the male and $52 \%$ of the female participants reported long-term unresolved grief.

In further analysis of the data stratified by gender, not having had an okay way to grieve $(R)$ was found to be statistically significantly associated with long-term unresolved grief in cancer-bereaved youths, both male (OR: 5.9, 95\% CI: 3.4-10.3) and female (OR: 2.9, 95\% CI: $1.8-$ 5.0). These associations remained significant for both 
Table 2 Prevalence of acute grief experiences and reactions (in the first 6 months post-loss) ( $N=622$ )

\begin{tabular}{|c|c|c|c|c|c|}
\hline $\begin{array}{l}\text { For the first half-year after your loss, would you agree } \\
\text { with the statement } \\
\text { (see phrasing in italics below): }\end{array}$ & $\begin{array}{l}\text { Do not agree } \\
\mathrm{N}(\%)\end{array}$ & $\begin{array}{l}\text { Slightly } \\
\text { agree } \\
\mathrm{N}(\%)\end{array}$ & $\begin{array}{l}\text { Moderately } \\
\text { agree } \\
\mathrm{N}(\%)\end{array}$ & $\begin{array}{l}\text { Completely } \\
\text { agree } \\
\mathrm{N}(\%)\end{array}$ & $\begin{array}{l}\text { Missing } \\
\mathbf{N}^{1}\end{array}$ \\
\hline $\begin{array}{l}\text { DID NOT HAVE AN OKAY WAY TO GRIEVE" } \\
\text { "I did not have a way to grieve that felt okay." }\end{array}$ & $107 / 614(17)$ & $158 / 614(26)$ & $227 / 614(37)$ & $122 / 614(20)$ & 8 \\
\hline $\begin{array}{l}\text { NUMBING AND POSTPONING } \\
\text { "I clenched my teeth, built a wall around me and lived on as if } \\
\text { nothing had happened." }\end{array}$ & $117 / 616(19)$ & 239/616 (39) & 148/616 (24) & 113/616 (18) & 6 \\
\hline $\begin{array}{l}\text { CONCEALED GRIEF } \\
\text { "I witheld my grief to protect my other parent." }\end{array}$ & $266 / 615(43)$ & 199/615 (32) & $97 / 615(16)$ & $53 / 615(9)$ & 7 \\
\hline $\begin{array}{l}\text { OVERWHELMED BY GRIEF } \\
\text { "The grief was so strong it felt as if I would not survive, as if I was } \\
\text { going crazy or was not normal." }\end{array}$ & $280 / 616(45)$ & $186 / 616(30)$ & $89 / 616(14)$ & $61 / 616(10)$ & 6 \\
\hline $\begin{array}{l}\text { DISCOURAGED FROM GRIEVING } \\
\text { "People stopped me from grieving by drawing away when I was } \\
\text { sad or praising me when I was being strong." }\end{array}$ & $349 / 613(57)$ & $171 / 613(28)$ & $60 / 613(10)$ & $33 / 613(5)$ & 9 \\
\hline $\begin{array}{l}\text { PRESSURED TO GRIEVE } \\
\text { "There was pressure from others that I should be more sad than } \\
\text { I was showing." }\end{array}$ & $328 / 616(53)$ & $172 / 616(28)$ & 78/616 (13) & $38 / 616(6)$ & 6 \\
\hline
\end{tabular}

${ }^{1}$ Individuals with missing data are excluded from the prevalence calculations

${ }^{2}$ To facilitate comparisons and avoid double negations, we here present the variable "I had a way to grieve that felt okay" as its negative counterpart,

"I did not have a way to grieve that felt okay"

genders throughout the adjustments. However, only among the male participants were numbing and postponing (OR: 1.73, 95\% CI: 1.22-2.47), overwhelmed by grief (OR: 2.02, 95\% CI: 1.35-3.04) and concealed grief (OR: 2.19, 95\% CI: 1.13-4.31) statistically significantly associated with long-term unresolved grief. These associations either remained or were strengthened after adjustments (Table 3). For female participants, the association with long-term unresolved grief was found for those reporting having been discouraged from grieving (OR: 2.76, 95\% CI: 1.49-5.32). The association remained statistically significant and more or less unchanged after adjustments for background, and family and health carerelated variables.

Possible predictive factors for having had an okay way to grieve in the first 6 months post-loss

Nine out of 28 background, family, and health carerelated variables were found to be statistically significantly associated with having had an okay way to grieve, based on the results of a univariate logistic regression (see Supplementary Table). These nine variables were then used in a multivariable logistic regression model (Table 4), where three of them were found to be statistically significantly associated with having had an okay way to grieve. Male participants were more likely to have had an okay way to grieve (OR: 1.77, 95\% CI: 1.23$2.54)$. Those who stated that there was a good family cohesion during the first 6 months after the loss (OR: 2.17, 95\% CI: 1.27-3.84), and those who reported that they had talked with the dying parent about what was important were more likely to have had an okay way to grieve than those who did not and wished they had (OR: 2.00, 95\% CI: 1.35-2.97).

\section{Discussion}

This exploratory nationwide population-based study of 622 parentally bereaved former teenagers shows that more than half of the participants had not found an okay way to grieve in the first 6 months after the loss. Not having had an okay way to grieve, and four out of the five other acute grief experiences and reactions, including numbing and postponing, concealing the grief to protect the surviving parent, and being overwhelmed by grief, were associated with long-term unresolved grief. Differences were found between male and female participants in their reported grief experiences and reactions during the acute bereavement phase. Male participants, those who had talked with the dying parent about what they perceived as important, and those who had good family cohesion after the loss were more likely to have had an okay way to grieve in the immediate post-loss phase.

To the best of our knowledge, this is the first documentation of the prevalence or even existence of a number of different acute grief experiences and reactions post-loss in bereaved teenagers and the association of these experiences with long-term grief resolution. While some of them (e.g. numbing and postponing, concealed grief, or being overwhelmed by grief) are known reactions to loss and have been mentioned, in some form, in other studies [26, 27, 29, 30, 54-56], this is, as far as we know, the first study where teenagers were asked if they had found a way to grieve that felt okay to them. These 
Table 3 Acute grief experiences and reactions, and the association with long-term unresolved grief

\begin{tabular}{|c|c|c|c|c|c|}
\hline & RATIOS & ODDS RATIOS (ORs) & $\begin{array}{l}\text { ODDS RATIOS } \\
\text { ADJUSTED FOR } \\
\text { BACKGROUND }^{\text {VARIABLES }^{1}}\end{array}$ & $\begin{array}{l}\text { ODDS RATIOS } \\
\text { ADJUSTED FOR } \\
\text { BACKGROUND } \\
\text { AND FAMILY- } \\
\text { RELATED } \\
\text { VARIABLES }{ }^{2}\end{array}$ & $\begin{array}{l}\text { ODDS RATIOS } \\
\text { ADJUSTED FOR } \\
\text { BACKGROUND, } \\
\text { FAMILY AND } \\
\text { HEALTH CARE- } \\
\text { RELATED } \\
\text { VARIABLES } \\
\end{array}$ \\
\hline & $\begin{array}{l}\mathrm{N} \text { unresolved grief }{ }^{4} / \\
\mathrm{N} \text { grieving style (\%) }\end{array}$ & OR $(95 \% \mathrm{Cl})$ & OR $(95 \% \mathrm{Cl})$ & OR $(95 \% \mathrm{Cl})$ & OR $(95 \% \mathrm{Cl})$ \\
\hline \multicolumn{6}{|c|}{ DID NOT HAVE AN OKAY WAY TO GRIEVE } \\
\hline Entire group Agree & $187 / 290(64)$ & $4.32(2.99-6.28)$ & $4.23(2.91-6.22)$ & $4.19(2.88-6.16)$ & $4.14(2.77-6.23)$ \\
\hline Entire group Disagree & $69 / 233(30)$ & 1.0 (ref) & 1.0 (ref) & 1.0 (ref) & 1.0 (ref) \\
\hline Male participants Agree & $75 / 118(64)$ & $5.85(3.41-10.25)$ & $6.23(3.59-11.07)$ & $6.64(3.79-11.98)$ & $6.72(3.65-12.84)$ \\
\hline Male participants Disagree & $31 / 135(23)$ & 1.0 (ref) & 1.0 (ref) & 1.0 (ref) & 1.0 (ref) \\
\hline Female participants Agree & $112 / 172(65)$ & $2.95(1.77-4.96)$ & $2.94(1.75-4.98)$ & $2.84(1.68-4.85)$ & $2.73(1.54-4.89)$ \\
\hline Female participants Disagree & 38/98 (39) & 1.0 (ref) & 1.0 (ref) & 1.0 (ref) & 1.0 (ref) \\
\hline \multicolumn{6}{|l|}{ NUMBING AND POSTPONING } \\
\hline Entire group Agree & $120 / 210(57)$ & $1.73(1.22-2.47)$ & $1.68(1.17-2.40)$ & $1.66(1.16-2.38)$ & $1.57(1.07-2.30)$ \\
\hline Entire group Disagree & $137 / 315(43)$ & 1.0 (ref) & 1.0 (ref) & 1.0 (ref) & 1.0 (ref) \\
\hline Male participants Agree & 48/94 (51) & $1.8(1.08-3.03)$ & $1.83(1.09-3.09)$ & $1.91(1.13-3.25)$ & $2.08(1.16-3.79)$ \\
\hline Male participants Disagree & $59 / 161(37)$ & 1.0 (ref) & 1.0 (ref) & 1.0 (ref) & 1.0 (ref) \\
\hline Female participants Agree & $72 / 116(62)$ & $1.59(0.98-2.61)$ & $1.51(0.92-2.50)$ & $1.58(0.95-2.63)$ & $1.43(0.82-2.48)$ \\
\hline Female participants Disagree & $78 / 154(51)$ & 1.0 (ref) & 1.0 (ref) & 1.0 (ref) & 1.0 (ref) \\
\hline \multicolumn{6}{|c|}{ CONCEALED GRIEF (TO PROTECT MY LIVING PARENT) } \\
\hline Entire group Agree & $80 / 133(60)$ & $1.83(1.23-2.73)$ & $1.71(1.14-2.60)$ & $1.64(1.08-2.53)$ & $1.56(1.00-2.45)$ \\
\hline Entire group Disagree & 177/391 (45) & 1.0 (ref) & 1.0 (ref) & 1.0 (ref) & 1.0 (ref) \\
\hline Male participants Agree & 25/43 (58) & $2.19(1.13-4.31)$ & $2.27(1.16-4.50)$ & $2.55(1.27-5.19)$ & $3.41(1.55-7.77)$ \\
\hline Male participants Disagree & $82 / 211(39)$ & 1.0 (ref) & 1.0 (ref) & 1.0 (ref) & 1.0 (ref) \\
\hline Female participants Agree & $55 / 90(61)$ & $1.41(0.84-2.37)$ & $1.45(0.86-2.47)$ & $1.20(0.69-2.09)$ & $1.04(0.57-1.88)$ \\
\hline Female participants Disagree & $95 / 180(53)$ & 1.0 (ref) & 1.0 (ref) & 1.0 (ref) & 1.0 (ref) \\
\hline \multicolumn{6}{|l|}{ OVERWHELMED BY GRIEF } \\
\hline Entire group Agree & $81 / 131(62)$ & $2.02(1.35-3.04)$ & $1.85(1.21-2.86)$ & $1.81(1.18-2.80)$ & $1.88(1.19-2.98)$ \\
\hline Entire group Disagree & $175 / 393(45)$ & 1.0 (ref) & 1.0 (ref) & 1.0 (ref) & 1.0 (ref) \\
\hline Male participants Agree & $17 / 28(61)$ & $2.35(1.06-5.40)$ & $2.54(1.13-5.94)$ & $2.73(1.20-6.45)$ & $3.22(1.29-8.34)$ \\
\hline Male participants Disagree & $90 / 227(40)$ & 1.0 (ref) & 1.0 (ref) & 1.0 (ref) & 1.0 (ref) \\
\hline Female participants Agree & $64 / 103(62)$ & $1.56(0.95-2.59)$ & $1.59(0.96-2.67)$ & $1.53(0.91-2.59)$ & $1.64(0.95-2.88)$ \\
\hline Female participants Disagree & $85 / 166(51)$ & 1.0 (ref) & 1.0 (ref) & 1.0 (ref) & 1.0 (ref) \\
\hline \multicolumn{6}{|l|}{ DISCOURAGED FROM GRIEVING } \\
\hline Entire group Agree & $54 / 78(69)$ & $2.68(1.62-4.56)$ & $2.37(1.41-4.08)$ & $2.31(1.37-3.99)$ & $2.45(1.42-4.32)$ \\
\hline Entire group Disagree & 203/445 (46) & 1.0 (ref) & 1.0 (ref) & 1.0 (ref) & 1.0 (ref) \\
\hline Male participants Agree & $9 / 17(53)$ & $1.60(0.59-4.39)$ & $1.67(0.61-4.64)$ & $1.75(0.64-4.92)$ & $2.1472(0.72-6.54)$ \\
\hline Male participants Disagree & $98 / 237(41)$ & 1.0 (ref) & 1.0 (ref) & 1.0 (ref) & 1.0 (ref) \\
\hline Female participants Agree & 45/61 (74) & $2.76(1.49-5.32)$ & $2.79(1.50-5.41)$ & $2.65(1.41-5.19)$ & $2.74(1.41-5.53)$ \\
\hline Female participants Disagree & $105 / 208(50)$ & 1.0 (ref) & 1.0 (ref) & 1.0 (ref) & 1.0 (ref) \\
\hline \multicolumn{6}{|l|}{ PRESSURED TO GRIEVE } \\
\hline Entire group Agree & $46 / 91(51)$ & $1.08(0.69-1.69)$ & $1.07(0.68-1.71)$ & $1.04(0.65-1.66)$ & $1.10(0.67-1.80)$ \\
\hline Entire group Disagree & 211/433 (49) & 1.0 (ref) & 1.0 (ref) & 1.0 (ref) & 1.0 (ref) \\
\hline Male participants Agree & $18 / 39(46)$ & $1.22(0.61-2.43)$ & $1.25(0.62-2.51)$ & $1.30(0.64-2.62)$ & $1.76(0.79-3.92)$ \\
\hline
\end{tabular}


Table 3 Acute grief experiences and reactions, and the association with long-term unresolved grief (Continued)

\begin{tabular}{|c|c|c|c|c|c|}
\hline & RATIOS & ODDS RATIOS (ORs) & $\begin{array}{l}\text { ODDS RATIOS } \\
\text { ADJUSTED FOR } \\
\text { BACKGROUND } \\
\text { VARIABLES }^{1}\end{array}$ & $\begin{array}{l}\text { ODDS RATIOS } \\
\text { ADJUSTED FOR } \\
\text { BACKGROUND } \\
\text { AND FAMILY- } \\
\text { RELATED } \\
\text { VARIABLES }{ }^{2}\end{array}$ & $\begin{array}{l}\text { ODDS RATIOS } \\
\text { ADJUSTED FOR } \\
\text { BACKGROUND, } \\
\text { FAMILY AND } \\
\text { HEALTH CARE- } \\
\text { RELATED } \\
\text { VARIABLES }\end{array}$ \\
\hline & $\begin{array}{l}\mathrm{N} \text { unresolved grief }{ }^{4} \text { / } \\
\mathrm{N} \text { grieving style (\%) }\end{array}$ & OR $(95 \% \mathrm{Cl})$ & OR $(95 \% \mathrm{Cl})$ & OR $(95 \% \mathrm{Cl})$ & OR $(95 \% \mathrm{Cl})$ \\
\hline Male participants Disagree & $89 / 216(41)$ & 1.0 (ref) & 1.0 (ref) & 1.0 (ref) & 1.0 (ref) \\
\hline Female participants Agree & $28 / 52(54)$ & $0.91(0.50-1.68)$ & $0.93(0.50-1.73)$ & $0.87(0.47-1.64)$ & $0.85(0.44-1.68)$ \\
\hline Female participants Disagree & $122 / 217(56)$ & 1.0 (ref) & 1.0 (ref) & 1.0 (ref) & 1.0 (ref) \\
\hline
\end{tabular}

Acute grief experiences and reactions: first 6 months post-loss. Long-term unresolved grief: 6-9 years post-loss. Agree: moderately agree and completely agree; Disagree: do not agree and slightly agree

Variables retained after the logistic regression in the forward selection procedure, using the variables as predictors of unresolved grief, with selection being based on likelihood ratio $p$-values and the entry criterion of $P<0.25$ : ${ }^{1}$ Odds ratio adjusted for background variables: gender (in the entire group, not used in the genderstratified data analysis), age at loss. ${ }^{2}$ Odds ratio adjusted for family-related variables: worried about the surviving parent. ${ }^{3}$ Odds ratio adjusted for health care-related variables: the teenager's perception of the health care professionals' efforts to cure the parent; the teenager's perception of the health care professionals' efforts to prolong the parent's life; whether the family had been given end-of-life information about the disease, treatment and death by a physician; whether the teenager had talked with their dying parent about what was important; awareness time at which the teenager realized that the parent would die from the disease; awareness time at which the teenager realized that death was imminent (hours or days)

${ }^{4}$ Missing values for unresolved grief (not included in the analyses): $n=63$; demographic variables: $n=89$; family-related variables: $n=13$; health care-related variables: $n=115$. Missing values are due to participants' response of "I don't know or remember" to selected variables. $C l C o n f i d e n c e$ interval. OR Odds ratio

thoughts were expressed by the bereaved teenagers themselves in the preparatory interviews and therefore included in the study-specific questionnaire.

Why so many of the parentally bereaved teenagers in our study seem to have been struggling with finding a way to grieve that felt okay to them during the acute bereavement phase is unclear to us. One possible explanation could be linked to the quality of their relationship with the surviving parent, where warmth and connection as well as positive parenting skills have been shown to benefit the children $[2,16,25,57-60]$. Also, how the surviving parent is coping with their own grief has been shown to have an impact on their children's grief reactions and ability to cope with the loss [59, 61-64]. Cancer, as the cause of death, has been found to significantly impact the risk of complicated grief among the bereaved [65], and may also be an explanation. Another possible explanation to consider, might be related to lack of experience and knowledge about common grief reactions in young people. More knowledge about what to expect

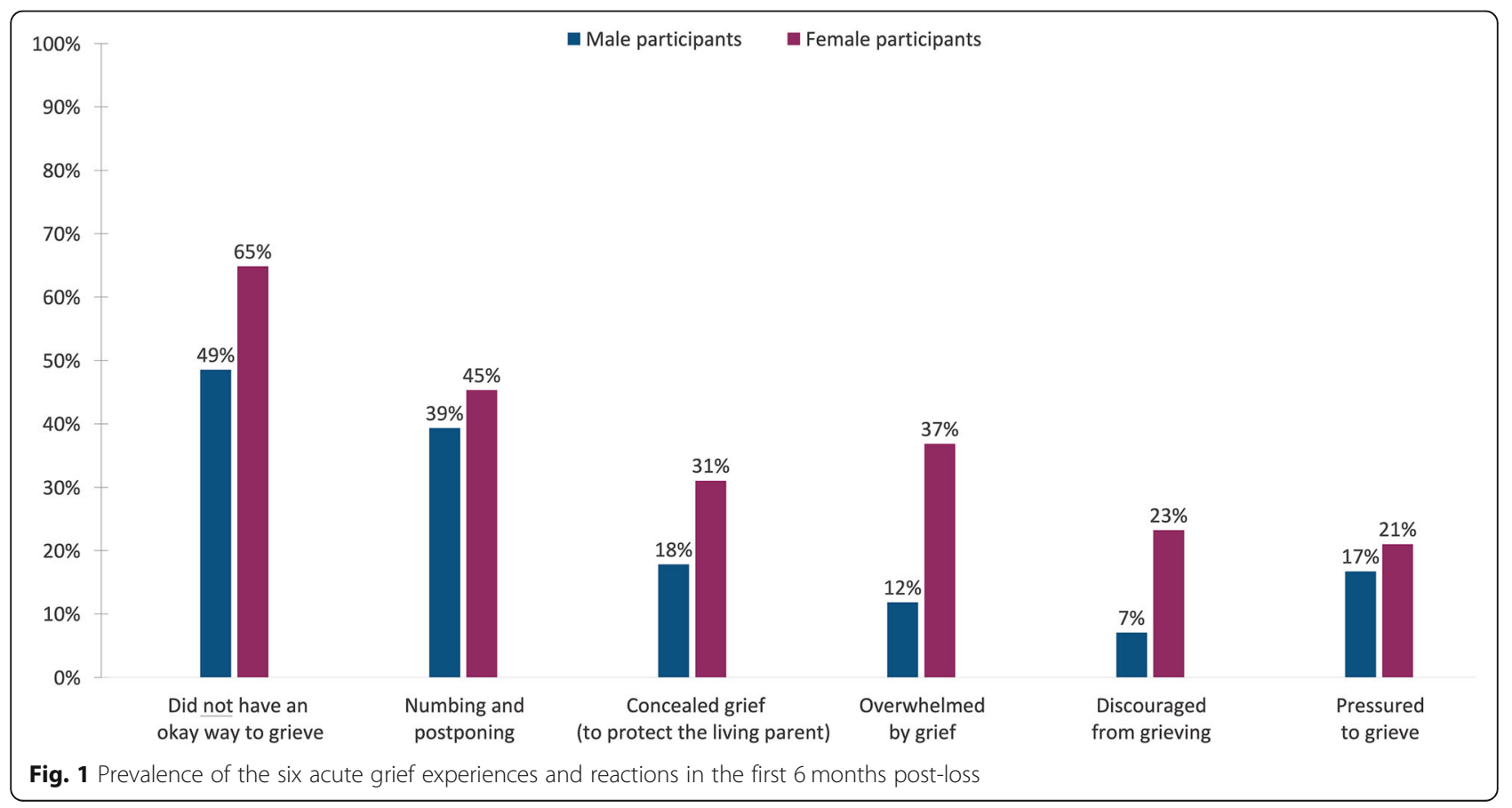




\section{Male participants $\quad$ Female participants}

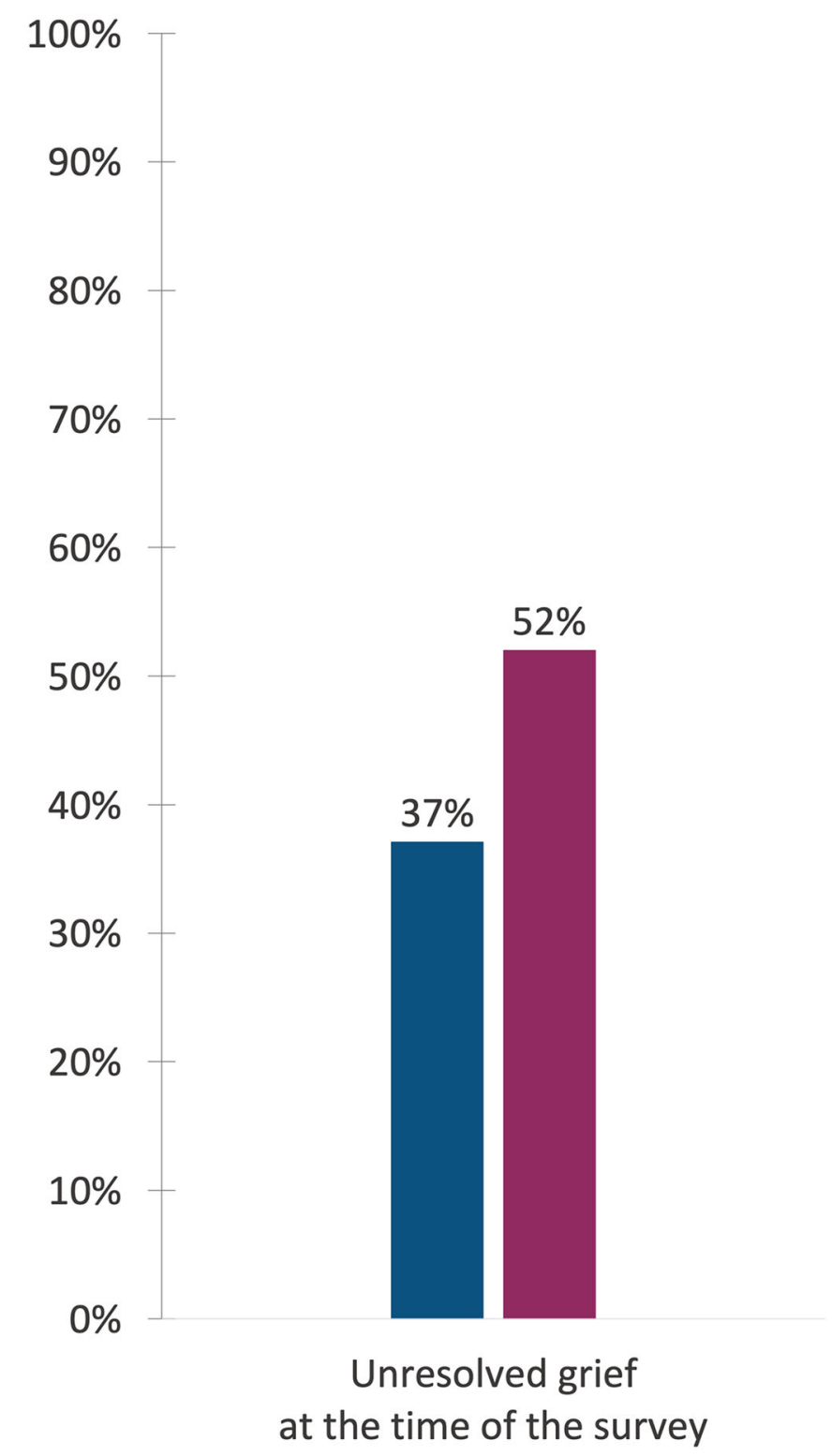

Fig. 2 Prevalence of long-term grief resolution at the time of the survey (6-9years post-loss)

after the death of a parent has been requested by bereaved teenagers and their surviving parents [39-41] and identified as helpful in their grieving process. It is also possible that more support is required according to individual needs after the death of a parent [66].

Numbing and postponing the grief was prevalent among the participants of our study. Although coping strategies that involve avoiding or suppressing emotions have been linked to psychological problems in bereaved children and teenagers and an open expression of grief is encouraged [67], it has also been argued that numbing and postponing grief can be an important part of their way to handle the grief [67]. Teenagers' developmental stage can make them especially vulnerable to emotional stressors [68] and they are often only capable of dealing with the emotional pain for a short period of time [33-35]. The Dual Process Model describes an oscillation which is viewed as a normal part of the grieving process, allowing the person to move in and out of intense grief, and thus enabling them to deal with the loss in small doses at a time [31, 32]. We do not know whether the reported numbing and postponing 
Table 4 Associations between possible predictive variables and having had an okay way to grieve in the first 6 months post-loss

\begin{tabular}{|c|c|c|c|}
\hline & $\begin{array}{l}\mathrm{N} \text { who had had an } \\
\text { okay way to grieve/ } \\
\mathrm{N} \text { of individuals in } \\
\text { the category (\%) }\end{array}$ & $\begin{array}{l}\text { OR }(95 \% \mathrm{Cl}) \text { of having had } \\
\text { an okay way to grieve } 1\end{array}$ & $P$-value \\
\hline Gender of participants & & & 0.0020 \\
\hline Male & $156 / 303(51)$ & $1.77(1.23-2.54)$ & \\
\hline Female & 109/310 (35) & 1.0 (ref) & \\
\hline Family cohesion during the teenage years, until the loss & & & 0.1459 \\
\hline Good (moderate, or very much cohesion) & $254 / 563(45)$ & $1.86(0.81-4.68)$ & \\
\hline Poor (no, or a little cohesion) & 9/48 (19) & 1.0 (ref) & \\
\hline Family cohesion during the first 6 months after the loss & & & 0.0046 \\
\hline Good (moderate, or very much cohesion) & 239/502 (48) & $2.17(1.27-3.84)$ & \\
\hline Poor (no, or a little cohesion) & $23 / 109(21)$ & 1.0 (ref) & \\
\hline $\begin{array}{l}\text { Worried about the surviving parent the first } 6 \text { months after } \\
\text { the loss }\end{array}$ & & & 0.0817 \\
\hline No (no, or a little worry) & 104/206 (50) & $1.40(0.96-2.05)$ & \\
\hline Yes (moderate, or very much worry) & $161 / 407(40)$ & 1.0 (ref) & \\
\hline $\begin{array}{l}\text { The teenager's level of trust in the care provided to the } \\
\text { dying parent in the final week of life }\end{array}$ & & & 0.5463 \\
\hline Trust (moderate, or very much trust) & 218/485 (45) & $1.19(0.68-2.08)$ & \\
\hline Distrust (no, or a little trust) & $34 / 103(33)$ & 1.0 (ref) & \\
\hline $\begin{array}{l}\text { The teenager's perception of the health care professionals' } \\
\text { efforts to cure their parent }\end{array}$ & & & 0.3045 \\
\hline Good efforts (moderate, or very much) & $212 / 451(47)$ & $1.37(0.75-2.54)$ & \\
\hline Poor efforts (no, or a little) & $52 / 160(32)$ & 1.0 (ref) & \\
\hline $\begin{array}{l}\text { The teenager's perception of the health care professionals' } \\
\text { efforts to prolong the parent's life }\end{array}$ & & & 0.6002 \\
\hline Good efforts (moderate, or very much) & $211 / 459(46)$ & $0.84(0.43-1.62)$ & \\
\hline Poor efforts (no, or a little) & $53 / 152(35)$ & 1.0 (ref) & \\
\hline $\begin{array}{l}\text { The teenager's perception of the health care professionals' } \\
\text { efforts to prevent the parent's suffering }\end{array}$ & & & 0.1760 \\
\hline Good efforts (moderate, or very much) & 240/524 (46) & $1.54(0.82-2.94)$ & \\
\hline Poor efforts (no, or a little) & 24/86 (28) & 1.0 (ref) & \\
\hline $\begin{array}{l}\text { The teenager had talked with their dying parent about } \\
\text { what was important }\end{array}$ & & & 0.0015 \\
\hline Yes & $118 / 225(52)$ & $2.00(1.35-2.97)$ & \\
\hline No, but I didn't feel a need to & $52 / 100(52)$ & $1.79(1.08-2.97)$ & \\
\hline No, and I wish I had & $92 / 280(33)$ & 1.0 (ref) & \\
\hline
\end{tabular}

${ }^{1}$ Multivariable model of background, family and health care-related variables that were statistically significantly associated $(p<0.05)$ in the bivariable analysis with having had an okay way to grieve

Missing values: 53 individuals were excluded because of missing values for any of the variables included in the model

$\mathrm{Cl}$ Confidence interval; OR Odds ratio

among our participants was part of oscillating coping as described by the Dual Process Model, enabling them to handle their emotional pain from the grief, or whether they were putting their grief reactions on hold for a longer period of time.

Out of the six different acute grief reactions and experiences in our study, not having had an okay way to grieve was the factor that had the strongest association with long-term unresolved grief. A study of bereaved adults [29] found that having negative interpretations of one's own grief reactions had a strong association with bereavement distress and symptoms of traumatic grief, even when those grief reactions are generally considered to be part of a normal grieving process [29]. This 
highlights the importance of encouraging or supporting bereaved teenagers to find a way of coming to terms with their own grief reactions.

Further analysis, based on the gender of the participants, showed that the female participants had a higher prevalence of all the different acute grief experiences and reactions compared to the male participants, and the female participants were more likely to report unresolved grief 6-9 years after the loss. In addition, we also found different acute grief reactions to be associated with unresolved grief in the cancer-bereaved male and female participants. However, not having had an okay way to grieve was found to be statistically significantly associated with unresolved grief in both genders.

There could be many reasons behind the identified gender differences. Although the literature on teenagers' grief reactions is still limited, previous research has shown differences in grief reactions between the genders, where girls have been shown to report more persistent grief responses than boys and to be more likely to have prolonged grief disorder than boys [69]. It has also been reported that both normative and problematic grief responses decline more slowly in girls than in boys [69]. Regardless of why these differences in experience between the genders occur, we could assume, based on our findings, that there might be a need to approach teenage boys and girls differently during the acute bereavement phase.

Apart from the association between being male and having had an okay way to grieve during the acute bereavement phase, we also found an association between good family cohesion after the loss and having had an okay way to grieve during the acute bereavement phase. This is in line with previous research where family function, including family cohesion, was shown to impact children's way of coping with loss $[2,4]$ and where bereavement support, with focus on improving the family function after the loss of a parent, was shown to be beneficial for children and teenagers [69-71].

We also found that those who had talked with the dying parent about what they perceived as important were more likely to have had an okay way to grieve in the acute post-loss phase. The vast majority of cancerbereaved teenagers want to be told about the ill parent's impending death [72] and being prepared for the loss of a parent has been shown to be of importance for children's adjustments after the loss [41]. In families where children are able to openly communicate about their parent's death, the children tend to adapt better in bereavement [73]. Children and teenagers have highlighted the importance of having the opportunity to say goodbye $[39,66,74,75]$ and those who were unable to have their final talk with their dying parent have reported resentment and sadness during their grief [76, 77]. However, for them to be able to have this opportunity, it is important for the health care personnel to communicate to the family, including the teenage offspring, when the death of a parent is near.

\section{Strengths and limitations}

This population-based survey was conducted with a large sample, using study-specific questions based on preparatory interviews with, and tested for face validity in, the target group. It also included measurement of a number of potential confounders. This, together with a high response rate (73\%) and the data collection method (with self-reported data collected directly from the former teenagers themselves, thus providing direct insight into the grief experiences and reactions of our target group) are the major strengths of our study.

Among the limitations, which should be considered when interpreting our results, are that we have no knowledge about the possible impact that unknown confounders or the responses from non-participants could have had on the results. That is, we do not know if those who declined participation in the study had more or less difficulties with grief than those who participated (i.e. potential selection bias). Not using standardized griefmeasurements can be seen as a limitation. However, our intention was to study the participants' subjective grief experiences and we believe using global single-item questions, directly asking about the real-life phenomena under investigation, can also be considered a strength. The questions were well understood by all of the bereaved participants in the face-validity interviews in this and other studies [50-52] and in this case it allowed us to collect a comprehensive data on teenagers' own subjective experience when losing a parent to cancer.

Because of our study design, i.e. cross-sectional, we cannot rule out the possibility of recall-induced bias and that current grief resolution may have partly influenced some participants' self-assessment of past events and circumstances. However, for ethical and practical reasons, collecting this data prospectively in a cohort study design was not possible. Instead, we had to mimic a longitudinal study design by anchoring the questions in childhood, teenage years, pre and post loss and today (at the time of the survey). In addition, we cannot know for what length of time our participants experienced the reported grief reactions and experiences, i.e. whether their answers reflected the whole first 6 months post-loss or whether the reactions occurred for a shorter part of that time. It is also noteworthy that in our exploratory study we found that $13 \%$ of the participants disagreed with all six of the statements regarding grief experiences, indicating a need to further explore other possible grief experiences and reactions that were not captured here. 
Also, the eligibility criteria limit the generalizability of our findings to other groups such as teenagers from single-parent households, newly arrived immigrants or children outside the age range of this study.

\section{Implications}

To be able to adjust to life after loss, both teenagers and their parents may benefit from knowledge of what to expect and the variety of grief reactions $[39,40]$. The findings from our study indicate that it is important not to impose specific expectations on how the teenager's grief should or should not be expressed or dealt with. Rather, we should try to gain a deeper understanding of how the young person experiences their own reactions and if they are okay with that or not. The findings that more than half of the participants did not have a way to grieve that felt okay to them during the acute bereavement phase and that many of them felt the need to suppress or conceal their grief to protect others, highlight the importance of attending to the needs of bereaved teenagers and encouraging them to find a way to grieve that feels okay to them. Further research probing deeper into what constitutes an okay way to grieve and what does not would be useful.

Regarding clinical implications, pre-loss communication between health care professionals and the family might facilitate the possibility to say goodbye. Health care professionals should be aware of the impact of good family cohesion and communication [37, 40, 41, 78] and facilitate it when a parent is seriously ill or dying, as this may potentially prevent long-term unresolved grief in bereaved youth. This could e.g. mean providing information about various grief reactions, screening for families and teenagers at risk for complicated grief and provide support as needed, such as through the Family bereavement program [69] or its Swedish adaptation; The Grief and Communication Family Support Intervention [79]. Apart from the role health care professionals can have in bereavement support it is also important to take more of a public health approach [80, 81]. Public awareness about the impact of social support, not only from the family but also from e.g. school professionals and peers $[82,83]$ may improve the wellbeing of bereaved youth.

\section{Conclusion}

More than half of the parentally bereaved participants had not found a way to grieve that felt okay to them during the acute bereavement phase. This, as well as several of the acute grief experiences and reactions measured, was associated with unresolved long-term grief. Having had an okay way to grieve in the immediate post-loss phase was predicted by male gender, good family cohesion and having had a last conversation with the dying parent. Pre- and post-loss communication between health care professionals and the family, including the teenage children, about the imminent death, and about common acute grief experiences and reactions, normalizing the sometimes abysmal emotions that may be experienced, could facilitate coping with grief in the acute phase of bereavement, thus possibly reducing the risk of unresolved long-term grief.

\section{Supplementary Information}

The online version contains supplementary material available at https://doi. org/10.1186/s12904-021-00758-7

Additional file 1: Supplementary Table. Associations between background, and family and health care-related variables and having had an okay way to grieve in the first 6 months post-loss.

\section{Acknowledgements}

We would like to thank all bereaved youth who so bravely shared their experiences with us. We acknowledge Else Lundin and Susanne Castells for assistance with data collection. We also wish to thank Elin Johnsson, a participant who decided to contact us during data collection, provided us with and allowed us to include the introductory quote, from her previously published book [1], in this article.

\section{Authors' contributions}

All authors meet the requirements for authorship. Contributors to the conception or design of the study or the acquisition of data: TBG, UK, GS, TN, CJF. Contributors to the design, analysis and interpretation of data for the work: DB, TBG, KB, TN, VS, GS, UK, JK. Contributors to drafting of the article: TBG, DB, UK, KB. Contributors to writing the main manuscript text and creating the figures and tables: DB, TBG, UK, KB. All authors contributed to revising the study critically for important intellectual content. All authors read and approved the final manuscript and agree to be accountable for all aspects of the work in ensuring that questions related to the accuracy or integrity of any part of the work are appropriately investigated and resolved. Tove Bylund Grenklo and Dröfn Birgisdóttir contributed equally to this paper and share co-first authorship.

\section{Funding}

The Swedish Cancer Foundation (2008-758); the Kamprad Family Foundation for Entrepreneurship; the Mats Paulsson Foundation; and the Gålö Foundation supported the research project. None of the funding sources have been involved in the study design, analysis, interpretation, writing or approval of the manuscript. Open Access funding provided by Lund University.

\section{Availability of data and materials}

The datasets generated and/or analysed during the current study are not publicly available due to legal and ethical restrictions as described by the Swedish law and ethical boards regarding data of sensitive nature, but are available from the corresponding authors on reasonable request. This is in order to assure data confidentiality and to protect the privacy of the research participants.

\section{Declarations}

\section{Ethics approval and consent to participate}

The research was conducted in accordance with the Helsinki Declaration and was reviewed by the Regional Ethics Review Board at the Karolinska Institute (2007/836-31), that gave approval for the research to be carried out. Each participant was informed both orally and in writing about the study objective, as well as their right to withdraw from the study at any time. Each participant gave informed consent for their own participation in accordance with the Swedish law. 


\section{Competing interests}

The authors have no conflict of interest to report.

\begin{abstract}
Author details
'Department of Caring Science, Faculty of Health and Occupational Studies, University of Gävle, SE-801 76 Gävle, Sweden. ${ }^{2}$ Faculty of Medicine, Department of Clinical Sciences Lund, Oncology and Pathology, Institute for Palliative Care, Lund University and Region Skåne, Medicon Village, Hus 404B, 22381 Lund, Sweden. ${ }^{3}$ Ghent University \& Vrije Universiteit Brussel (VUB), End-of-Life Care Research Group, Ghent, Belgium. ${ }^{4}$ Department of Public Health and Primary Care, Ghent University, Ghent, Belgium. ${ }^{5}$ MRC Biostatistics Unit, University of Cambridge, Cambridge, UK. ${ }^{6}$ Department of Oncology-Pathology, Karolinska Institute, Division of Clinical Cancer Epidemiology, Stockholm, Sweden. ${ }^{7}$ Faculty of Medicine, Department of Health Sciences, Lund University, Lund, Sweden. ${ }^{8}$ Department of Oncology, Sahlgrenska Academy at the University of Gothenburg, Division of Clinical Cancer Epidemiology, Institute of Clinical Sciences, Gothenburg, Sweden. ${ }^{9}$ Department of Caring Sciences, Ersta Sköndal Bräcke University College, Palliative Research Center, Stockholm, Sweden. ${ }^{10}$ Department of Women's and Children's Health, Karolinska Institutet, Stockholm, Sweden.
\end{abstract}

\section{Received: 27 November 2020 Accepted: 20 April 2021} Published online: 27 May 2021

\section{References}

1. Johnsson E. En liten bok om att stå bredvid. Vulkan: Stockholm; 2009. p. 86.

2. Brent DA, Melhem NM, Masten AS, Porta G, Payne MW. Longitudinal effects of parental bereavement on adolescent developmental competence. J Clin Child Adolesc Psychol. 2012;41(6):778-91. https://doi.org/10.1080/1537441 6.2012.717871

3. Luecken $\sqcup$, Roubinov DS. Pathways to lifespan health following childhood parental death. Soc Pers Psychol Compass. 2012;6(3):243-57. https://doi. org/10.1111/j.1751-9004.2011.00422.x.

4. Haine RA, Ayers TS, Sandler IN, Wolchik SA. Evidence-based practices for parentally bereaved children and their families. Prof Psychol Res Pract. 2008; 39(2):113-21. https://doi.org/10.1037/0735-7028.39.2.113.

5. Dowdney L. Children bereaved by parent or sibling death. Psychiatry. 2008; 7(6):270-5. https://doi.org/10.1016/j.mppsy.2008.04.007.

6. Buckley T, Mihailidou AS, Spinaze M, Tofler G, Bartrop R, Ward C, et al. Prospective study of early bereavement on psychological and behavioural cardiac risk factors. Intern Med J. 2009;39(6):370-8. https://doi.org/10.1111/ j.1445-5994.2008.01879.x

7. Cerel J, Fristad MA, Verducci J, Weller RA, Weller EB. Childhood bereavement: psychopathology in the 2 years Postparental death. J Am Acad Child Adolesc Psychiatry. 2006;45(6):681-90. https://doi.org/10.1097/01. chi.0000215327.58799.05

8. Jakobsen IS, Christiansen E. Young people's risk of suicide attempts in relation to parental death: a population-based register study. J Child Psychol Psychiatry. 2011;52(2):176-83. https://doi.org/10.1111/j.1469-7610.2 010.02298.x

9. Niederkrotenthaler T, Floderus B, Alexanderson K, Rasmussen F, Mittendorfer-Rutz E. Exposure to parental mortality and markers of morbidity, and the risks of attempted and completed suicide in offspring: an analysis of sensitive life periods. J Epidemiol Community Health. 2012; 66(3):233-9. https://doi.org/10.1136/jech.2010.109595.

10. Rostila M, Berg L, Arat A, Vinnerljung B, Hjern A. Parental death in childhood and self-inflicted injuries in young adults-a national cohort study from Sweden. Eur Child Adolesc Psychiatry. 2016;25(10):1103-11. https://doi.org/1 0.1007/s00787-016-0833-6.

11. Li J, Vestergaard M, Cnattingius S, Gissler M, Bech BH, Obel C, et al. Mortality after parental death in childhood: a Nationwide cohort study from three Nordic countries. PLoS Med. 2014;11(7):e1001679. https://doi.org/10.1371/ journal.pmed.1001679.

12. Bylund Grenklo T, Nyberg T, Steineck G, Fürst CJ, Kreicbergs U, Valdimarsdóttir UA. Self-injury in youths who lost a parent to cancer: Nationwide study of the impact of family-related and health-carerelated factors. Psycho-oncology. 2014;23(9):989-97. https://doi.org/10.1 002/pon.3515

13. Bylund Grenklo T, Kreicbergs U, Hauksdottir A, Valdimarsdottir UA, Nyberg T, Steineck $G$, et al. Self-injury in teenagers who lost a parent to cancer: a nationwide, population-based, long-term follow-up. JAMA Pediatr. 2013; 167(2):133-40. https://doi.org/10.1001/jamapediatrics.2013.430.

14. Worden JW, Silverman PR. Parental death and the adjustment of school-age children. OMEGA J Death Dying. 1996:33(2):91-102. https://doi.org/10.2190/ P77L-F6F6-5W06-NHBX.

15. Kaplow JB, Layne CM, Pynoos RS, Cohen JA, Lieberman A. DSM-V diagnostic criteria for bereavement-related disorders in children and adolescents: developmental considerations. Psychiatry Interpers Biol Process. 2012;75(3): 243-66. https://doi.org/10.1521/psyc.2012.75.3.243.

16. Lin KK, Sandler IN, Ayers TS, Wolchik SA, Luecken LJ. Resilience in parentally bereaved children and adolescents seeking preventive services. J Clin Child Adolesc Psychol. 2004;33(4):673-83. https://doi. org/10.1207/s15374424jccp3304_3.

17. Bylund-Grenklo T, Furst CJ, Nyberg T, Steineck G, Kreicbergs U. Unresolved grief and its consequences. A nationwide follow-up of teenage loss of a parent to cancer 6-9 years earlier. Support Care Cancer. 2016;24(7):3095-103. https://doi.org/10.1007/s00520-016-3118-1.

18. Birgisdóttir D, Bylund Grenklo T, Nyberg T, Kreicbergs U, Steineck G, Fürst CJ. Losing a parent to cancer as a teenager: family cohesion in childhood, teenage, and young adulthood as perceived by bereaved and nonbereaved youths. Psychooncology. 2019;28(9):1845-53. https://doi.org/10.1 002/pon.5163.

19. Melhem NM, Day N, Shear MK, Day R, Reynolds CF, Brent D. Predictors of complicated grief among adolescents exposed to a Peer's suicide. J Loss Trauma. 2004;9(1):21-34. https://doi.org/10.1080/1532502490255287.

20. Melhem NM, Porta G, Shamseddeen W, Walker Payne M, Brent DA. Grief in children and adolescents bereaved by sudden parental death. Arch Gen Psychiatry. 2011;68(9):911-9. https://doi.org/10.1001/archgenpsychiatry.2011.101.

21. Spuij M, Dekovic M, Boelen PA. An open trial of 'grief-help': a cognitivebehavioural treatment for prolonged grief in children and adolescents. Clin Psychol Psychother. 2015;22(2):185-92. https://doi.org/10.1002/cpp.1877.

22. Prigerson HG, Shear MK, Jacobs SC, Reynolds CF 3rd, Maciejewski PK, Davidson JR, et al. Consensus criteria for traumatic grief. A preliminary empirical test. Br J Psychiatry. 1999;174(1):67-73. https://doi.org/10.1192/ bjp.174.1.67.

23. Melhem NM, Porta G, Payne MW, Brent DA. Identifying prolonged grief reactions in children: dimensional and diagnostic approaches. J Am Acad Child Adolesc Psychiatry. 2013;52(6):599-607.e7.

24. Dyregrov A, Dyregrov K. Complicated grief in children - the perspectives of experienced professionals. Omega (United States). 2013;67(3):291-303.

25. Bui E. Clinical handbook of bereavement and grief reactions. Cham, Switzerland: Humana Press; 2017.

26. Bonanno GA, Kaltman S. The varieties of grief experience. Clin Psychol Rev. 2001;21(5):705-34. https://doi.org/10.1016/S0272-7358(00)00062-3.

27. Stroebe M, Schut $H$, Stroebe W. Health outcomes of bereavement. Lancet. 2007;370(9603):1960-73. https://doi.org/10.1016/S0140-6736(07)61816-9.

28. Prigerson HGH, Mardi, J.; Jacobs Selby, C, Colin MP, Mihaela A, Karl G, Beverley R, Samuel JM, et al. Prolonged grief disorder: psychometric validation of criteria proposed for DSM-V and ICD-11. PLoS Med. 2009;6(8): e1000121-e.

29. Boelen PA, van den Bout J, van den Hout MA. The role of negative interpretations of grief reactions in emotional problems after bereavement. J Behav Ther Exp Psychiatry. 2003;34(3):225-38. https://doi.org/10.1016/j. jbtep.2003.08.001.

30. Zisook S, Iglewicz A, Avanzino J, Maglione J, Glorioso D, Zetumer S, et al. Bereavement: course, consequences, and care. Curr Psychiatry Rep. 2014; 16(10):482. https://doi.org/10.1007/s11920-014-0482-8.

31. Stroebe M, Schut $H$. The dual process model of coping with bereavement: rationale and description. Death Stud. 1999;23(3):197-224. https://doi.org/1 0.1080/074811899201046.

32. Stroebe $M$, Schut $H$. The dual process model of coping with bereavement: a decade on. Omega J Death Dying. 2010;61(4):273-89. https://doi.org/10.21 90/OM.61.4.b.

33. Sood AB, Razdan A, Weller EB, Weller RA. Children's reactions to parental and sibling death. Curr Psychiatry Rep. 2006;8(2):115-20. https://doi.org/10.1 007/s11920-006-0008-0

34. Christ $\mathrm{GH}$. Impact of development on children's mourning. Cancer Pract. 2000;8(2):72-81. https://doi.org/10.1046/j.1523-5394.2000.82005.x.

35. Christ GH, Siegel K, Christ AE. Adolescent grief: "it never really hit me .. until it actually happened". Jama. 2002;288(10):1269-78. https://doi.org/10.1 001/jama.288.10.1269. 
36. Shulla RM, Toomey RB. Sex differences in behavioral and psychological expression of grief during adolescence: a meta-analysis. J Adolesc. 2018;65: 219-27. https://doi.org/10.1016/j.adolescence.2018.04.001.

37. Hoffmann R, Kaiser J, Kersting A. Psychosocial outcomes in cancer-bereaved children and adolescents: A systematic review. 2018. p. 2327-38.

38. Kaplow JB, Howell KH, Layne CM. Do circumstances of the death matter? Identifying Socioenvironmental risks for grief-related psychopathology in bereaved youth. J Trauma Stress. 2014;27(1):42-9. https://doi.org/10.1002/ jts.21877.

39. Dehlin L, Reg LM. Adolescents' experiences of a parent's serious illness and death. Palliat Support Care. 2009;7(1):13-25. https://doi.org/10.1017/S14 78951509000042.

40. Hanna JR, McCaughan E, Semple CJ. Challenges and support needs of parents and children when a parent is at end of life: a systematic review Palliat Med. 2019;33(8):1017-44. https://doi.org/10.1177/0269216319857622.

41. Dalton L, Rapa E, Ziebland S, Rochat T, Kelly B, Hanington L, et al. Communication with children and adolescents about the diagnosis of a lifethreatening condition in their parent. Lancet (London, England). 2019; 393(10176):1164-76.

42. Muriel AC, Moore CW, Beiser M, Park ER, Lim CT, Rauch P. What do surviving children wish for from a dying parent? A qualitative exploration. Death Stud. 2020;44(5):319-27. https://doi.org/10.1080/074 81187.2018.1554608.

43. Flahault C, Dolbeault S, Sankey C, Fasse L. Understanding grief in children who have lost a parent with cancer: how do they give meaning to this experience? Results of an interpretative phenomenological analysis. Death Stud. 2018:42(8):483-90. https://doi.org/10.1080/07481187.2017.1383951.

44. Patterson P, Rangganadhan A. Losing a parent to cancer: a preliminary investigation into the needs of adolescents and young adults. Palliat Support Care. 2010;8(3):255-65. https://doi.org/10.1017/S1478951510000052.

45. Berk LE, Part VI. Adolescence: The transition to adulthood. In: Berk LE, editor. Development through the lifespan. Fifth ed. Boston: Pearson; 2010.

46. Bylund GT. Teenagers losing a parent to cancer : experiences, modifiable riskfactors and long-term outcome [PhD]. Karolinska Institutet: Stockholm; 2013.

47. Omerov P, Steineck G, Runeson B, Christensson A, Kreicbergs U, Pettersen R, et al. Preparatory studies to a population-based survey of suicide-bereaved parents in Sweden. Crisis. 2013;34(3):200-10. https://doi.org/10.1027/02275910/a000175

48. Rådestad I, Steineck G, Nordin C, Sjögren B. Psychological complications after stillbirth: influence of memories and immediate management: population based study. BMJ Br Med J. 1996;7045:1505.

49. Steineck G, Bergmark K, Henningsohn L, Al-Abany M, Dickman PW, Helgason A. Symptom documentation in Cancer survivors as a basis for therapy modifications. Acta Oncol. 2002;41(3):244-52. https://doi.org/10.1 080/02841860260088782.

50. Kreicbergs UC, Lannen P, Onelov E, Wolfe J. Parental grief after losing a child to cancer: impact of professional and social support on long-term outcomes. J Clin Oncol. 2007;25(22):3307-12. https://doi.org/10.1200/JCO.2 006.10.0743

51. Lannen PK, Wolfe J, Prigerson HG, Onelov E, Kreicbergs UC. Unresolved grief in a national sample of bereaved parents: impaired mental and physical health 4 to 9 years later. J Clin Oncol. 2008;26(36):5870-6. https://doi.org/1 $0.1200 / J C O .2007 .14 .6738$

52. Lövgren M, Sveen J, Nyberg T, Eilegård Wallin A, Prigerson HG, Steineck G, et al. Care at end of life influences grief: a Nationwide long-term follow-up among young adults who lost a brother or sister to childhood Cancer. J Palliat Med. 2018;21(2):156-62. https://doi.org/10.1089/jpm.2017.0029.

53. Sveen J, Eilegård A, Steineck G, Kreicbergs U, Eilegard A. They still grieve - a nationwide follow-up of young adults 2-9 years after losing a sibling to cancer. Psychooncology. 2014;23(6):658-64. https://doi.org/1 0.1002/pon.3463.

54. Boelen PA, Spuij M, Reijntjes AHA. Prolonged grief and posttraumatic stress in bereaved children: a latent class analysis. Psychiatry Res. 2017;258:518-24. https://doi.org/10.1016/j.psychres.2017.09.002.

55. Boelen PA, van den Bout J, van den Hout MA. A prospective examination of catastrophic misinterpretations and experiential avoidance in emotional distress following loss. J Nerv Ment Dis. 2010;198(4):252-7. https://doi.org/1 0.1097/NMD.0b013e3181d619e4.

56. Boelen PA, van den Hout MA. The role of threatening misinterpretations and avoidance in emotional problems after loss. Behav Cogn Psychother. 2008;36(1):71-87. https://doi.org/10.1017/S1352465807004079.
57. Haine RA, Wolchik SA, Sandler IN, Millsap RE, Ayers TS. Positive parenting as a protective resource for parentally bereaved children. Death Stud. 2006; 30(1):1-28. https://doi.org/10.1080/07481180500348639.

58. Wolchik SA, Tein JY, Sandler IN, Ayers TS. Stressors, quality of the childcaregiver relationship, and children's mental health problems after parental death: the mediating role of self-system beliefs. J Abnorm Child Psychol. 2006;34(2):221-38. https://doi.org/10.1007/s10802-005-9016-5.

59. Shapiro DN, Howell KH, Kaplow JB. Associations among mother-child communication quality, childhood maladaptive grief, and depressive symptoms. Death Stud. 2014;38(3):172-8. https://doi.org/10.1080/07481187.2 012.738771.

60. Balk D. Adolescent development and bereavement: an introduction. Prev Res. 2011;18(3):3-9.

61. Wolchik S, Ma Y, Tein J-Y, Sandler I, Ayers T. Parentally bereaved Children's grief: self-system beliefs as mediators of the relations between grief and stressors and caregiver-child relationship quality. Death Stud. 2008;32(7): 597-620. https://doi.org/10.1080/07481180802215551.

62. Green EJ, Connolly ME. Jungian family sandplay with bereaved children: implications for play therapists. Int J Play Ther. 2009;18(2):84-98. https://doi. org/10.1037/a0014435

63. Howell KH, Barrett-Becker EP, Burnside AN, Wamser-Nanney R, Layne CM, Kaplow JB. Children facing parental cancer versus parental death: the buffering effects of positive parenting and emotional expression. J Child Fam Stud. 2016;25(1):152-64.

64. Field N, Tzadikario E, Pel D, Ret T. Attachment and mother-child communication in adjustment to the death of a father among Cambodian adolescents. J Loss Trauma. 2014;19(4):314-30. https://doi.org/10.1080/1532 5024.2013.780411.

65. Kersting A, Brahler E, Glaesmer H, Wagner B. Prevalence of complicated grief in a representative population-based sample. J Affect Disord. 2011;131(1-3): 339-43. https://doi.org/10.1016/j.jad.2010.11.032.

66. Alvariza A, Lovgren M, Bylund-Grenklo T, Hakola P, Furst CJ, Kreicbergs U. How to support teenagers who are losing a parent to cancer: bereaved young adults' advice to healthcare professionals-a nationwide survey. Palliat Support Care. 2017;15(3):313-19.

67. Howell KH, Shapiro DN, Layne CM, Kaplow JB. Individual and psychosocial mechanisms of adaptive functioning in parentally bereaved children. Death Stud. 2015;39(5):296-306. https://doi.org/10.1080/07481187.2014.951497.

68. Romeo R. The teenage brain: the stress response and the adolescent brain. Curr Dir Psychol Sci. 2013;22(2):140-5. https://doi.org/10.1177/09637214134 75445.

69. Sandler IN, Ma Y, Tein J-Y, Ayers TS, Wolchik S, Kennedy C, et al. Long-term effects of the family bereavement program on multiple indicators of grief in parentally bereaved children and adolescents. J Consult Clin Psychol. 2010; 78(2):131-43. https://doi.org/10.1037/a0018393.

70. Bergman A-S, Axberg U, Hanson E. When a parent dies - a systematic review of the effects of support programs for parentally bereaved children and their caregivers. BMC Palliat Care. 2017;16(1):39. https://doi.org/10.1186/ s12904-017-0223-y.

71. Weber Falk M, Alvariza A, Kreicbergs U, Sveen J. The grief and communication family support intervention: intervention fidelity, participant experiences, and potential outcomes. Death Stud. 2020:1-12. https://doi. org/10.1080/07481187.2020.1728429.

72. Bylund-Grenklo T, Kreicbergs U, Uggla C, Valdimarsdottir UA, Nyberg T, Steineck $G$, et al. Teenagers want to be told when a parent's death is near: a nationwide study of cancer-bereaved youths' opinions and experiences. Acta Oncol. 2015;54(6):944-50.

73. Fearnley R. Writing the 'penultimate chapter': how children begin to make sense of parental terminal illness. Mortality. 2015;20(2):163-77. https://doi. org/10.1080/13576275.2014.996209.

74. MacPherson C, Emeleus M. Children's needs when facing the death of a parent from cancer: part two. Int J Palliat Nurs. 2007;13(12):590-7. https:// doi.org/10.12968/ijpn.2007.13.12.27887.

75. Sheehan DK, Draucker CB. Interaction patterns between parents with advanced cancer and their adolescent children. Psychooncology. 2011; 20(10):1108-15. https://doi.org/10.1002/pon.1831.

76. Sheehan DK, Draucker CB, Christ GH, Mayo MM, Heim K, Parish S. Telling adolescents a parent is dying. J Palliat Med. 2014;17(5):512-20.

77. Tillquist M, Bäckrud F, Rosengren K. Dare to ask children as relatives! A qualitative study about female teenagers' experiences of losing a parent to 
cancer. Home Health Care Manag Pract. 2016;28(2):94-100. https://doi.org/1 $0.1177 / 1084822315610104$.

78. Angelhoff C, Sveen J, Alvariza A, Weber-Falk M, Kreicbergs U. Communication, self-esteem and prolonged grief in parent-adolescent dyads, 1-4 years following the death of a parent to cancer. Eur J Oncol Nurs. 2021;50:101883. https://doi.org/10.1016/j.ejon.2020.101883.

79. Weber Falk M, Salloum A, Alvariza A, Kreicbergs U, Sveen J. Outcomes of the grief and communication family support intervention on parent and child psychological health and communication. Death Stud. 2020:1-12. https://doi.org/10.1080/07481187.2020.1851816.

80. Aoun SM, Breen LJ, White I, Rumbold B, Kellehear A. What sources of bereavement support are perceived helpful by bereaved people and why? Empirical evidence for the compassionate communities approach. Palliat Med. 2018;32(8):1378-88. https://doi.org/10.1177/0269216318774995

81. Aoun SM, Breen $\amalg$, O'Connor M, Rumbold B, Nordstrom C. A public health approach to bereavement support services in palliative care. Aust N Z J Public Health. 2012;36(1):14-6. https://doi.org/10.1111/j.1753-6405.2012.00825.x

82. Dyregrov A, Dyregrov K, Lytje M. Loss in the family - a reflection on how schools can support their students. Bereavement Care. 2020;39(3):95-101. https://doi.org/10.1080/02682621.2020.1828722.

83. Holm M, Weber Falk M, Lövgren M, Kreicbergs U, Alvariza A, Sveen J. Sources of social support and its importance for cancer-bereaved spouses and their minor children: a cross-sectional study. Death Stud. 2020:1-7. https://doi.org/10.1080/07481187.2020.1780344.

\section{Publisher's Note}

Springer Nature remains neutral with regard to jurisdictional claims in published maps and institutional affiliations.

Ready to submit your research? Choose BMC and benefit from:

- fast, convenient online submission

- thorough peer review by experienced researchers in your field

- rapid publication on acceptance

- support for research data, including large and complex data types

- gold Open Access which fosters wider collaboration and increased citations

- maximum visibility for your research: over $100 \mathrm{M}$ website views per year

At $\mathrm{BMC}$, research is always in progress.

Learn more biomedcentral.com/submissions 